\title{
GROWTH OF BARE ROOT Pinus taeda, L. SEEDLINGS CULTIVATED UNDER FIVE DENSITIES IN NURSERY
}

\author{
José Geraldo de Araújo Carneiro ${ }^{1 *}$; Deborah Guerra Barroso ${ }^{1}$; Luis Maurício da Silva Soares ${ }^{1}$ \\ ${ }^{1}$ UENF/CCTA/LFIT, Av. Alberto Lamego, 2000 - Parque Califórnia - 28013-602 - Campos dos Goytacazes, RJ - \\ Brasil. \\ *Corresponding author <carneiro@uenf.br>
}

\begin{abstract}
Seedlings compete for nutrients, water and light. The available area for each seedling affects their behavior related to requirements for these resources. This experiment evaluated the influence of five plant densities on the growth of bare root Pinus taeda, L. seedlings in a nursery after outplanting. The analyzed characteristics were: height $(\mathrm{H})$, root collar diameter $(\mathrm{D}), \mathrm{H} / \mathrm{D}$ ratio, and dry matter weight. Higher densities stimulated $\mathrm{H}$ growth and the lowest densities increased $\mathrm{D}$ average and dry matter weight and lowered the H/D ratio. Seedlings were distributed by H, D and H/D classes. Higher densities had a larger number of seedlings in larger $\mathrm{H}$ classes. Larger numbers of seedlings with larger D and lower H/D ratios were found in lower densities. Ten months after outplanting the seedlings grown in lower densities had higher survival percentages and growth. Some saplings of standardized heights were uprooted with the objective of studying their root systems. The lowest densities stimulated higher numbers of first and second order roots as well as fresh and dry matter weights of thin roots with mycorrhizae presence. In both parts of the experiment, the density of 278 seedlings $\mathrm{m}^{-2}$ yielded equivalent averages as compared to the lowest densities.
\end{abstract}

Key words: spacing, erosion, seedling quality, morphological characteristics, root growth

\section{CRESCIMENTO DE MUDAS EM RAIZ NUA DE Pinus taeda, L. PRODUZIDAS EM CINCO DENSIDADES NO VIVEIRO}

\begin{abstract}
RESUMO: Mudas competem por nutrientes, água e luz. A área de cada muda afeta seu comportamento na exigência destes recursos. Este experimento avaliou a influência de cinco densidades no crescimento de mudas em raiz nua de Pinus taeda, L. no viveiro e no campo. As características analisadas foram: altura da parte aérea (H), diâmetro de colo (D), relação H/D e pesos de matéria seca. Maiores densidades estimularam o crescimento em $\mathrm{H}$, no viveiro. As mais baixas aumentaram as médias de $\mathrm{D}$, pesos de matéria seca e diminuíram a relação H/D. Distribuíram-se as mudas em classes de H, D e relação H/D, para quantificar seu número, em cada classe. Maiores quantidades de mudas com mais elevados valores de $\mathrm{D}$ e com menores valores de H/D foram encontrados nas densidades mais baixas. Um grande número de mudas com valores altos de $\mathrm{D}$ e menores da relação H/D foram encontrados nas mais baixas densidades. Dez meses após o plantio, as mudas produzidas nas densidades menores mostraram maiores percentuais de sobrevivência e crescimento. Algumas plantas foram arrancadas, objetivando o estudo de seus sistemas radiculares. As densidades mais baixas estimularam maior número de raízes de primeira e segunda ordens, assim como também pesos de matérias fresca e seca de raízes finas com presença de micorriza. Em ambas as partes do experimento, a densidade de 278 mudas por $\mathrm{m}^{-2}$ mostrou médias equivalentes , quando comparada com as menores densidades.

Palavras-chave: espaçamento, erosão, qualidade de mudas, características morfológicas, crescimento de raízes
\end{abstract}

\section{INTRODUCTION}

Forest seedling grading is motivated by two advantages (Carneiro, 1983): a) increase of survival percentage; b) decrease of the need for cultural cleanings after outplanting. Seedlings of low quality also present less growth during the first months in the field. José (2003) reports that the utilization of high quality seedlings (achieved with a selection of genetic material, cultural practices in the nursery and proper methodology for stand establishment) is one of the factors that ensures the success of outplantings.

Conditions at each nursery (like density, site - substrate quality and climate -variations in performance of seedlings due to seeds vigor, provenance, genetic origin and shading) differ so that there is great relevance in establishing criteria to evaluate seedling quality. Density is one of the most relevant factors to 
be studied due to its simultaneous influence on competition for nutrients, water and light.

Different methods have been used for the evalution of forest seedlings. However stem, diameter, fresh and dry matter weight (stem and root), root growth regenerating potential (number, length, root tip number, surface, volume and diameter) are probably the most commonly used criteria: (Daniel et al., 1994, Driessche, 1994, Oliveira Filho, 1994, Carneiro, 1995, Claussen, 1996, Reis et al., 1996, Tinus, 1996a; 1996b, Ferreira, 1997, Paula, 1997, Santos, 1998, Mohamed et al., 1998, Morgado et al., 2000, Bircher et al., 1998, South, 2000, Novaes et al., 2001; 2002 and Chaves et al., 2003). Density has a more critical effect on growth when compared to the available substrate volume (Brissette et al., 1991). Therefore, spacing is crucially important for producing high quality standard seedlings.

Different densities promote distinct selfshading levels in the beds. From a certain growth stage onward the allocation of photosynthetic products to the stem shifts in response to selfshading, changing the stem/ root relationship and the seedlings performance in the field (Mexal \& Landis, 1990). Stands established with a low standard of quality usually cause a reduction in the survival percentage and initial growth relative to expectation (Carneiro, 1995). Morphological stem and root growth characteristics have a strong influence on reforestation success. The choice of seedling cultivation techniques and their resulting quality demand more research. The correct methodology is not yet clear for the majority of species and sites. Negative consequences are slower growth after outplanting, higher blank-fillings and frequency of cleaning treatments.

The main objective of this experiment was to evaluate the influence of five densities of bare root Pinus taeda, L. seedlings on their performance in nurseries and in the field.

\section{MATERIAL AND METHODS}

The experiment was set up in a $\mathrm{Cfb}$ temperate climate (according to Köppen's classification) under wet conditions (Brasil, 1992). The yearly average temperatures are lower than $22^{\circ} \mathrm{C}$ in the warmest month and lower than $10^{\circ} \mathrm{C}$ in the coldest month, with an incidence of up to five frosts per year and an annual average rainfall of $1500 \mathrm{~mm}$ with regular distribution along the year. This region is located at a latitude of $22^{\circ} 26^{\prime} \mathrm{S}$, a longitude of $49^{\circ} 16^{\prime} \mathrm{W}$ and an altitude of $920 \mathrm{~m}$.

Soil samples of the $30 \mathrm{~cm}$ surface layer had the following physical characteristics: sand $\left(500 \mathrm{~g} \mathrm{~kg}^{-1}\right)$, silt $\left(220 \mathrm{~g} \mathrm{~kg}^{-1}\right)$ and clay $\left(280 \mathrm{~g} \mathrm{~kg}^{-1}\right)$, determined by the pipette method. Chemical characteristics: $\mathrm{pH}$ (water 1:2:5) 5.7; P, K, Cu, Zn, Fe and $\mathrm{Mn}\left(\mathrm{mg} \mathrm{dm}^{-3}\right)$ : 34, 99, 1.0, 3.1, 56 and 23.2, respectively - Mehlich-1 $\left(\mathrm{HCl} 0.05 \mathrm{M}+\mathrm{H}_{2} \mathrm{SO}_{4} 0.025 \mathrm{~N}\right) ; \mathrm{Ca}, \mathrm{Mg}$ and $\mathrm{H}+\mathrm{Al}$ $\left(\mathrm{mmol}_{\mathrm{c}} \mathrm{dm}^{-3}\right)$ : 20, 18 and 1 , respectively $(\mathrm{HCl} 1 \mathrm{~N})$.

The experiment covered two phases: bare root seedling cultivation in full light and the monitoring of their performance in the field. In the first phase treatments were composed of five plant densities: 2,500 seedlings $\mathrm{m}^{-2}(2 \times 2 \mathrm{~cm}) ; 625$ seedlings $\mathrm{m}^{-2}(4 \times 4 \mathrm{~cm})$; 278 seedlings $\mathrm{m}^{-2}(6 \times 6 \mathrm{~cm}) ; 156$ seedlings $\mathrm{m}^{-2}(8 \times 8$ $\mathrm{cm})$ and 100 seedlings $\mathrm{m}^{-2}(10 \times 10 \mathrm{~cm})$.

Eight months after sowing the following morphological plant characteristics were measured: stem height $(\mathrm{H})$, root collar diameter (D), H/D ratio and dry matter weight (top, root and total). Seedlings were oven dried at $105^{\circ} \mathrm{C}(\mathrm{Böhm}, 1991)$ to a constant weight. At this time, samples were sorted into $\mathrm{H}, \mathrm{D}$ and $H / D$ classes with the aim of quantifying the size class distribution of seedlings. The interval widths were $3 \mathrm{~cm}$ for $\mathrm{H}, 1 \mathrm{~mm}$ for $\mathrm{D}$, and 2 for $\mathrm{D} / \mathrm{H}$. The chisquare test showed differences among the intervals for each class, and the $\mathrm{H}_{0}$ hipothesis was rejected, at an alpha level of $5 \%$.

For the first phase, the experimental design was totally randomized with three replicates of each density assigned to $1.0 \mathrm{~m}^{-2}$ plots. Fifty seedlings from each plot, were sampled for all characteristics. Due to the variation in the seedling frequency among the replications in the same treatment, the averages were weighed. Barttlet and chi-square tests presented homogeneity of the variance for all variables except for the survival percentages. Lilliefors and chi-square tests were also used to compare the independence among the variables. After analysis of variance, the Duncan Test was used at an alpha level of 5\%, also in the second phase.

For the second phase, seedlings were outplanted in a uniform fertile and deep soil. Survival was monitored monthly until the tenth month. The survival percentages $(\mathrm{P})$ were transformed through $\sqrt{100-P}$, according to the statement of Steel \& Torrie (1960): "Percentage data based on counts where the range of percentages is 0 to $20 \%$ or 80 to $100 \%$ (but not both) may also be analyzed by using the square root transformation. Percentages between 80 and 100 should be subtracted from 100 before the transformation is made." Freeze (1967) came to the same conclusion. After the transformation, the Barttlet test was used again to prove that the experimental errors were normally distributed. Since all the requirements for the valid application of significance tests were fulfilled, the analysis of variance and Duncan Test were applied to the data at the level of $5 \%$. 
Tukey's test is not recommended to be used in experiments in biological research (due to the inherent variability of biological data), because it induces to the error of type II (accept the null hypothesis even when it is false). Duncan's is the multiple range test that best balances errors of types I and II. Tukey and Duncan tests have very similar basis, but the Duncan test establishes a half-term between the excessive severity of Tukey test and the exaggerated lack of rigour of $\underline{\mathbf{t}}$ test (Pimentel-Gomes \& Garcia, 2002). Height growth and the Root Regenerating Potential (RRP) were also evaluated, according to Böhm (1991) and Carneiro (1995). For this purpose two plants of standardized height were carefully harvested from each plot. First the average height of those and their standard deviations were calculated. The samples were the plants with height between $+1 / 3$ to $-1 / 3$ of the standard deviation. The RRP was assessed by counting the number of secondary roots of first and second orders with diameter equal or larger to $1.0 \mathrm{~mm}$ and by determining fresh and dry weights of fine and mychorriza roots whose diameters were less than $1.0 \mathrm{~mm}$ (both measured at their insertion points).

The second phase of the experiment followed a completely randomized block design with three replications. Each plot area was $10 \times 12 \mathrm{~m}$, with thirty seedlings arranged in six lines of five seedlings, with a spacing of two meters. After analysis of variance, the Duncan Test was used at an alpha level of $5 \%$.

\section{RESULTS AND DISCUSSION}

The use of a single characteristic is not the best way to evaluate seedling quality (Schmidt-Vogt, 1966; and Carneiro, 1995). Any reliable measure of seedling potential considers several characteristics. Analysis of variance of the measurements of all studied characteristics, eight months after the sowing presented differences among the densities (Table 1).

The averages of all seedling characteristics cultivated in the highest density are different from those cultivated in lower ones. The highest density $(2,500$ seedlings $/ \mathrm{m}^{-2}$ ) was not suitable for high quality seedling cultivation. Leopold \& Kriedeman (1975) indicate that the effects of lower densities on dry root matter may be explained through the higher incidence of light and less selfshading, resulting in a higher photosynthetic efficiency. Density indicates the degree of competition for growth between seedlings with consequences on the ability to assimilate light, water and nutrients. Seedlings growing in high densities may show low physiological quality and low performance in the field (Carneiro, 1995; Kramer \& Rose, 1985). Seedlings of the three lowest densities were not significantly different for dry weight (Table 1). Brissette et al. (1991) also found that dry root weight of Pinus seedlings increased for lower plant densities. José (2003) found higher dry root matter averages for Schinus terebinthifolia Raddi and Guazuma ulmifolia Lam. seedlings, when cultivated in tubes (50 and 150 $\mathrm{mL}$ ), that had greater spacing between containers.

At the highest density larger percentages of the seedlings were in the largest height classes (Figure 1) and the spacings widened mode of the $\mathrm{H}$ distribution moved to the lower classes. The opposite effect is observed for the distribution of seedlings by root collar diameter classes (Figure 2).

Similar distributions of H/D were observed for the three lowest densities (Figure 3). The two higher densities exhibited larger H/D ratios. The seedling density of $278 / \mathrm{m}^{-2}$ was apparently appropriate for Pinus taeda, L. seedlings to maintain an acceptable H/D.

Low H/D ratios have been regarded as indicating well-balanced seedlings with greater growth and vigor (Schmidt-Vogt, 1966, Carneiro, 1995). A low H/D ratio ensures that the seedlings are more resistant against wind and drought, and promotes higher survival and growth on dry sites (Johnson \& Cline (1991). However, the inherent deficiency of this characteristic as a way of classifying seedling quality is that the roots are not taken into account (Carneiro, 1995). Table 2 shows the frequency of seedlings distribution into $\mathrm{H}, \mathrm{D}$ and $\mathrm{H} / \mathrm{D}$ classes.

Table 1- Growth averages among five spacing treatments of Pinus taeda, L. eight months after the sowing (150 bare root seedlings).

\begin{tabular}{|c|c|c|c|c|c|c|}
\hline \multirow{2}{*}{ Densities } & \multirow{2}{*}{$\begin{array}{c}\text { Stem height } \\
(\mathrm{H})\end{array}$} & \multirow{2}{*}{$\begin{array}{l}\text { Root collar } \\
\text { diameter (D) }\end{array}$} & \multirow{2}{*}{$\mathrm{H} / \mathrm{D}$ ratio } & \multicolumn{3}{|c|}{ Dry matter weight } \\
\hline & & & & Stem & Root & Total \\
\hline $\mathrm{m}^{-2}$ & $\mathrm{~cm}$ & $\mathrm{~mm}$ & & (n) & --- g - & (n......... \\
\hline 2,500 & $17.47 \mathrm{ab}$ & $1.95 \mathrm{a}$ & $9.45 \mathrm{a}$ & $0.35 \mathrm{a}$ & $0.17 \mathrm{a}$ & $0.52 \mathrm{a}$ \\
\hline 625 & $18.33 \mathrm{a}$ & $3.42 \mathrm{~b}$ & $5.56 \mathrm{a}$ & $0.94 \mathrm{~b}$ & $1.21 \mathrm{a}$ & $2.15 \mathrm{~b}$ \\
\hline 278 & $15.49 \mathrm{ab}$ & $3.69 \mathrm{bc}$ & $4.36 \mathrm{~b}$ & $1.20 \mathrm{c}$ & $1.62 \mathrm{~b}$ & $2.82 \mathrm{c}$ \\
\hline 156 & $14.68 \mathrm{~b}$ & $4.17 \mathrm{bc}$ & $3.61 \mathrm{~b}$ & $1.22 \mathrm{c}$ & $1.70 \mathrm{~b}$ & $2.92 \mathrm{c}$ \\
\hline 100 & $14.74 \mathrm{~b}$ & $4.65 \mathrm{c}$ & $3.25 \mathrm{~b}$ & $1.37 \mathrm{c}$ & $1.72 \mathrm{~b}$ & $3.09 \mathrm{c}$ \\
\hline
\end{tabular}

Averages followed by the same letter in the column do not differ by the Duncan test $(P<0.05)$.

Sci. Agric. (Piracicaba, Braz.), v.64, n.1, p.23-29, January/February 2007 

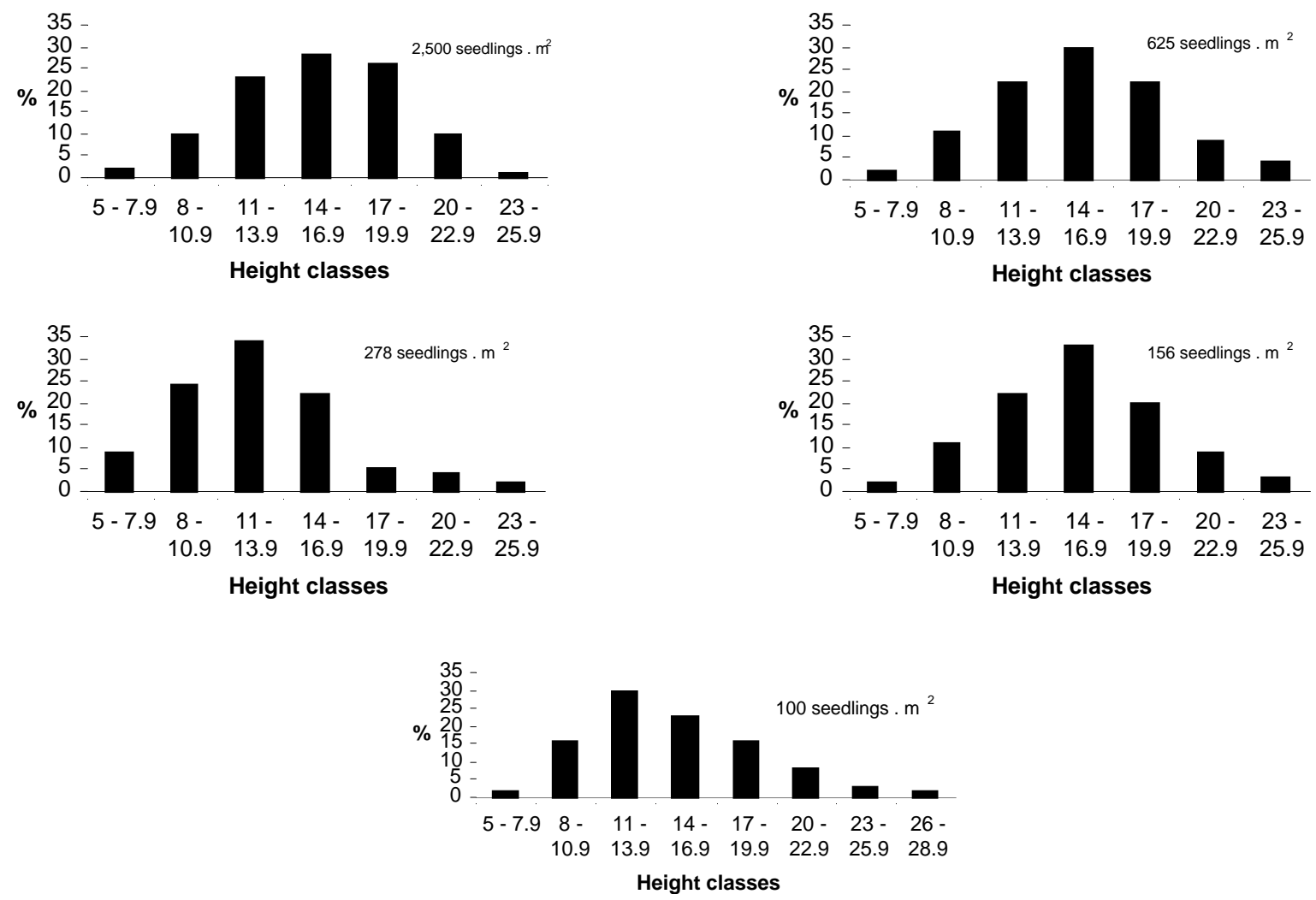

Figure 1- Frequency (\%) of Pinus taeda,L. seedling in height classes $(\mathrm{cm})$ eight months after the sowing.
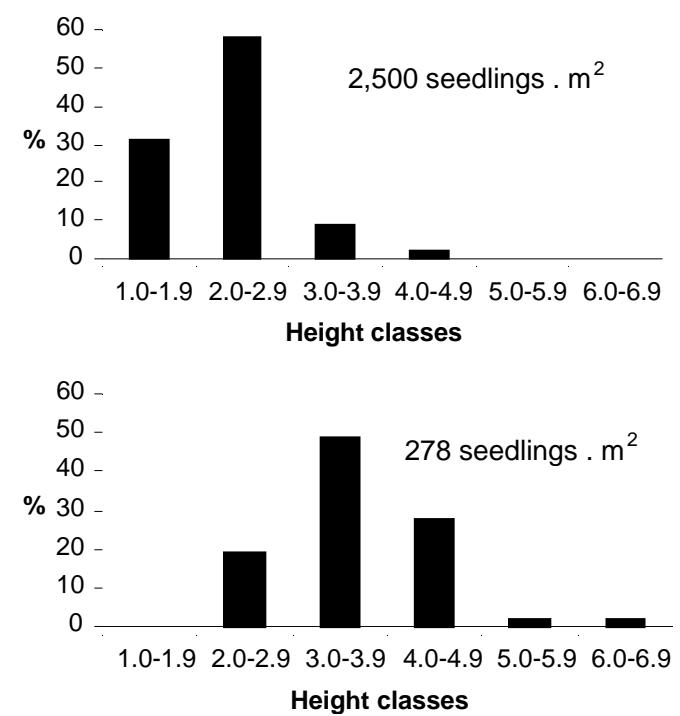
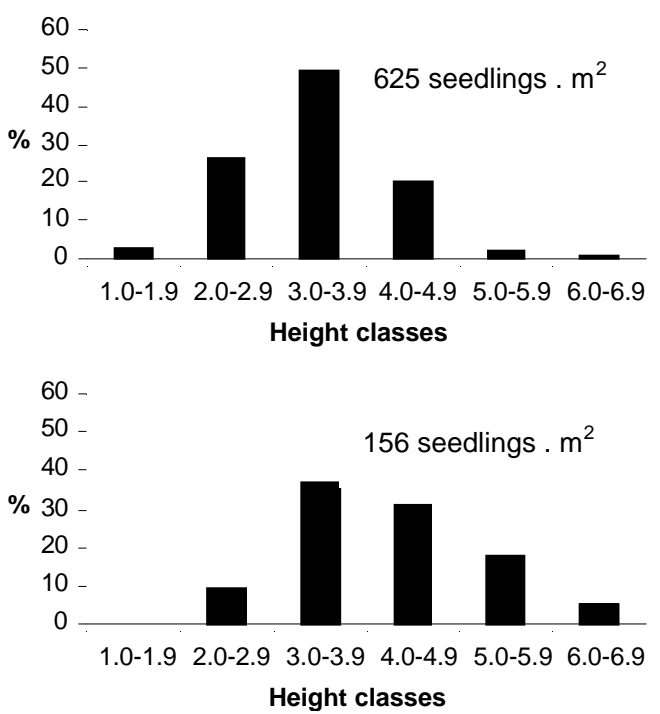

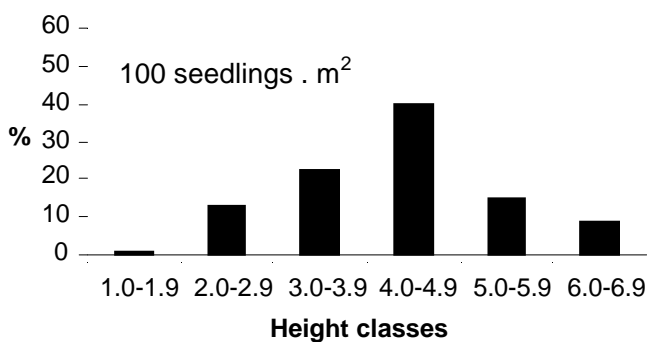

Figure 2 - Frequency (\%) of Pinus taeda, L. seedling distribution in root collar diameter classes (mm) eight months after the sowing.

Sci. Agric. (Piracicaba, Braz.), v.64, n.1, p.23-29, January/February 2007 

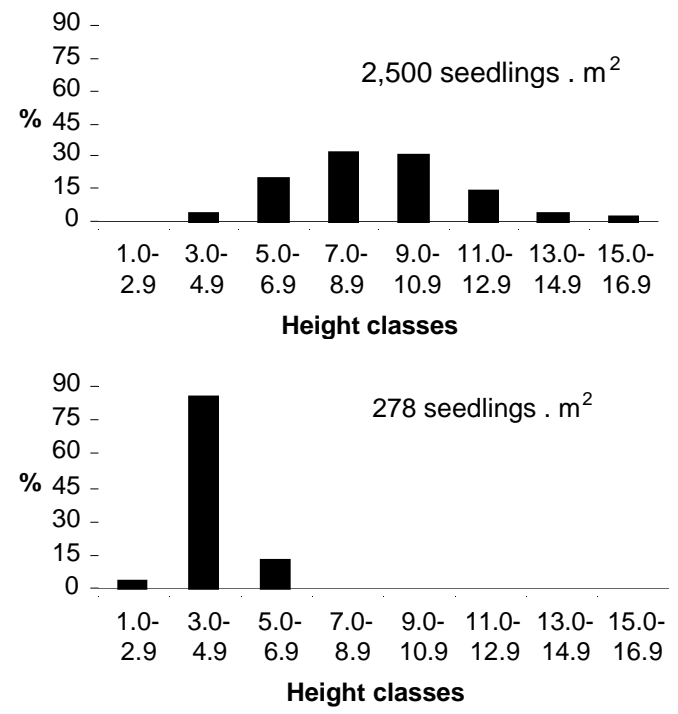
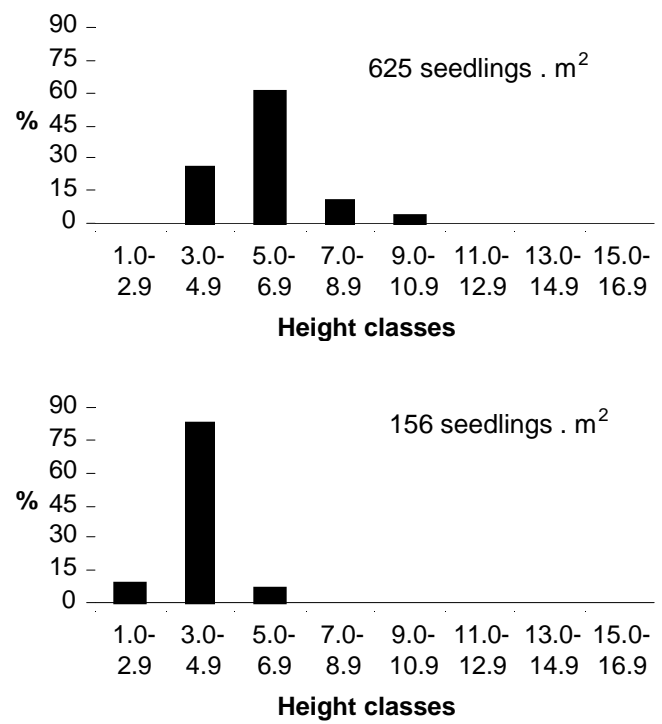

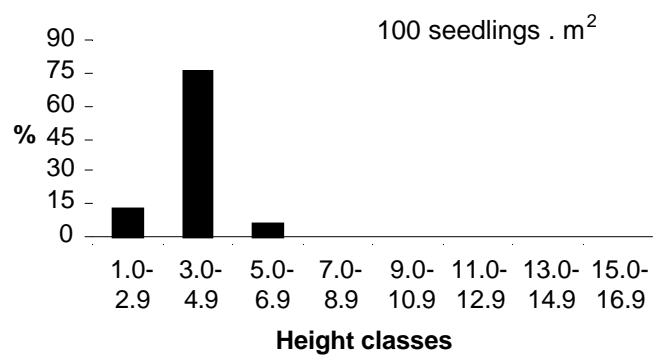

Figure 3 - Frequency (\%) of Pinus taeda L. seedling distribution in height / diameter ratio (H/D) classes eight months after the sowing.

Table 2 - Frequency (\%) of Pinus taeda, L. seedling distribution in height $(\geq 17.0 \mathrm{~cm})$, root collar diameter $(\geq 4.0 \mathrm{~mm})$ and $\mathrm{H} / \mathrm{D}(\geq 9.0)$ classes eight months after the sowing.

\begin{tabular}{lccc}
\hline \multirow{2}{*}{ Densities } & \multicolumn{2}{c}{ Stem } & H/D \\
\cline { 2 - 4 } & Height $(\mathrm{H})$ & Diameter (D) & Ratio \\
\hline $\mathrm{m}^{-2}$ & $\mathrm{~cm}$ & $\mathrm{~mm}$ & \\
2,500 & 65 & 2 & 49 \\
625 & 65 & 23 & 3 \\
278 & 33 & 32 & 0 \\
156 & 32 & 54 & 0 \\
100 & 29 & 64 & 0 \\
\hline
\end{tabular}

The ideal nursery density depends on the species, fertility and conditions of the site, and does not need to be standardized for all nurseries (Wakeley, 1954; Carneiro, 1983). The goal should be a maximum quantity of seedlings with morphological quality at low costs. More fertile substrates tolerate higher density as long as this density does not impede light penetration among seedlings.

Ten months after outplanting no difference was found in the survival. The results for decreasing plant densities were: 82.2, 95.5, 98.9, 95.5 and 98.9\%. Height growth was also evaluated after 10 months. South (2000) also studied the performance of bare root Pinus seedlings and verified that when grown in low densities seedlings presented higher survival percentages and growth rates. The change in survival between the $1^{\text {st }}$ and the $10^{\text {th }}$ evaluations and height growth are shown in Table 3.

The results for height growth show the same significant equivalence between densities of 2,500, 625 and 156 seedlings per square meter, but not for survival. McTague \& Tinus (1996) found a positive relationship between height and survival for Pinus taeda seedlings. However, for Mexal \& Landis (1990), this was not a characteristic that showed correlation with survival percentage. According to these authors, smaller seedlings with higher root collar diameters are more suitable for arid sites and taller seedlings should be used where there is weed competition. Taller seedlings have also been shown to exhibit a lower survival rate (Undström \& Keane 1999). Taller stem heights imply in a higher available foliar area for photosynthesis and transpiration and have an advantage in sites where the weed competition poses a problem (Kiiskila, 2003). 
Table 3 - Average growth characteristics of three replications (90 seedlings) of Pinus taeda, L., ten months after the outplanting.

\begin{tabular}{lccc}
\hline \multirow{2}{*}{ Seedling } & \multirow{2}{*}{ Stem height } & \multicolumn{2}{c}{ Survival percentage (months) } \\
\cline { 3 - 4 } & $\mathrm{cm}$ & $1^{\text {st }}$ & $10^{\text {th }}$ \\
\hline $\mathrm{m}^{-2}$ & $44.0 \mathrm{a}$ & $94.4 \mathrm{a}$ & $82.2 \mathrm{a}$ \\
2,500 & $53.1 \mathrm{ab}$ & $100 \mathrm{~b}$ & $95.6 \mathrm{~b}$ \\
625 & $55.4 \mathrm{~b}$ & $100 \mathrm{~b}$ & $98.9 \mathrm{c}$ \\
278 & $54.0 \mathrm{ab}$ & $100 \mathrm{~b}$ & $99.0 \mathrm{c}$ \\
156 & $57.2 \mathrm{~b}$ & $100 \mathrm{~b}$ & $98.9 \mathrm{c}$ \\
100 &
\end{tabular}

Averages followed by the same letter in the column do not differ by the Duncan Test $(P<0.05)$

Ten months after outplanting the three lowest densities had the greatest survival rate. The density of 278 seedlings $\mathrm{m}^{-2}$ had the same advantages as compared to the lower densities. Barros et al. (1978) found that height growth was inversely proportional to stem height at the outplanting time for Eucalyptus grandis seedlings. Gomes \& Paiva (2004) recommended defining a standardized stem height prior to outplanting and noted that this subject requires further investigation. Some of these inconsistencies may be connected to differences in soil and climate conditions of outplanting sites and to seedling production methods. In higher densities the occurrence of selfshading can also cause the seedlings to dry up or lose their leaves at the bottom of the stem.

The RRP, also known as Root Growth Potential, is recognized as an important factor to evaluate seedling quality (Böhm 1991). He described root measurement methods and emphasized the significance of some characteristics, such as the root number. The genetic potential of the seeds and the environmental conditions also influence seedling survival and their performance in the field (South, 2000).

Ten months after outplanting, two plants of stem height close to the average in each plot were carefully uprooted (Table 4).

No difference was found among the plant densities relative to the first order roots. However, the highest density presented lower number of second order roots. The importance of the verified number of second order roots must also be emphasized. This result was similar to that of fine $(\mathrm{d} \geq 1 \mathrm{~mm})$ root weight as well. These observations may explain the lower $10^{\text {th }}$ survival percentages of the seedlings cultivated in highly restrictive densities. Morgado et al. (2000) also studied RRP of Eucalypthus grandis seedlings. They counted the number of the regenerated roots, the newly
Table 4 - Root growth of Pinus taeda, L., seedlings shown by root number at their insertion point, ten months after the outplanting.

\begin{tabular}{llrlc}
\hline \multirow{2}{*}{ Density } & \multicolumn{2}{c}{$\begin{array}{l}\text { Secondary } \\
\text { number }(\geq 1 \mathrm{~mm})\end{array}$} & \multicolumn{2}{c}{$\begin{array}{c}\text { root } \\
\text { (root } \geq 1 \mathrm{~mm})\end{array}$} \\
\cline { 2 - 5 } & $\begin{array}{l}\text { First } \\
\text { Order }\end{array}$ & $\begin{array}{r}\text { Second } \\
\text { Order }\end{array}$ & Fresh & Dry \\
\hline 2,500 & $20 \mathrm{a}$ & $67 \mathrm{a}$ & $2.8 \mathrm{a}$ & $1.43 \mathrm{a}$ \\
625 & $29 \mathrm{a}$ & $125 \mathrm{~b}$ & $2.9 \mathrm{a}$ & $1.57 \mathrm{~b}$ \\
278 & $30 \mathrm{a}$ & $120 \mathrm{~b}$ & $3.3 \mathrm{~b}$ & $1.63 \mathrm{~b}$ \\
1568 & $31 \mathrm{a}$ & $128 \mathrm{~b}$ & $3.03 \mathrm{~b}$ & $1.53 \mathrm{~b}$ \\
100 & $31 \mathrm{a}$ & $135 \mathrm{~b}$ & $3.77 \mathrm{~b}$ & $1.9 \mathrm{~b}$ \\
\hline
\end{tabular}

Averages followed by the same letter in the column do not differ by the Duncan Test $(P<0.05)$

regenerated root tips and root length. Differences were observed suggesting that RRP may be a reliable physiological characteristic to assess seedling quality. Differences in stem height and root collar diameter of the seedlings were also observed in the field. Leles (1998) studied the RRP of Eucalyptus camaldulensis, E. grandis and E. pellita according to the same methodology utilized by Morgado et al. (2000) and found that seedlings had a high survival percentage when cultivated in pressed blocks and showed a better growth rate performance, height, and diameter at the soil level after outplanting. Seedlings with higher average root number, length and newly regenerated tips in rhizotrons presented reliable prognosis related to field performance.

\section{CONCLUSIONS}

High densities for Pinus taeda, L. seedling cultivation should be avoided, since they do not stimulate adequate growth conditions, causing negative effects on the quality of the nursery stock during the first months after outplanting. In nurseries Pinus taeda, L. seedlings should be cultivated using a density of 278 seedlings $\mathrm{m}^{-2}$ to attain a high standard of quality for outplanting.

\section{REFERENCES}

BARROS, N.F.; BRANDI, R.M.; COUTO, L.; REZENDE, G.C. Efeitos de recipientes na sobrevivência e no crescimento de mudas de Eucalyptus grandis W. Hill. Ex-maiden, no viveiro e no campo. Revista Árvore, v.2, p.141-151, 1978.

BIRCHER, T.; ROSE, R.W.; ROYO, A.; PARDOS, M. La planta ideal: revisión del concepto, parametros definitorios y implementación practica. Investigation Agrária. Sistemas y Recursos Forestales, v.7, p.109-121, 1998.

BÖHM, W. Methods of studying root systems. Berlin: Springer-Verlag, 1991. 188p.

BRASIL. Ministério da Agricultura e Reforma Agrária. Normas climatológicas $(1961$ - 1990). Brasília: 1992. 84p. 
BRISSETTE, J.C. Development and function of the root systems of southern pine nursery stock. In: SOUTHERN FOREST NURSERY ASSOCIATION, New York, 1991. Proceedings. New York: USDA, Southern Forest Experiment Station, 1991. p.67-81.

BRISSETTE, J.C.; BARNETT, J.P.; LANDIS. T.D. Container seedlings. In: DURYEA, M.L.; DOUGHERTY, P.M. (Ed.). Forest regeneration manual. Dordrecht: Kluwer Academic Publishers, 1991. p.117-142.

CARNEIRO, J.G. de A. Variações na metodologia de produção de mudas florestais afetam os parâmetros morfofisiológicos que indicam sua qualidade. Fupef, v.12, p.1-40, 1983.

CARNEIRO, J.G. de A. Métodos de produção e controle de qualidade de mudas florestais. Curitiba: Universidade Federal do Paraná; Campos dos Goytacazes: Universidade Estadual do Norte Fluminense Darcy Ribeiro, 1995. 451p.

CHAVES, de L.B.; CARNEIRO, J.G.A.; BARROSO, D.G.; LELES, P.S. dos S. Efeitos da inoculação com rizóbio e da adubação nitrogenada na produção de mudas de sesbânia, em substrato constituído de resíduos agroindustriais. Revista Árvore, v.27, p.443449, 2003

CLAUSSEN, J.W. Acclimation abilities of three tropical rainforest seedlings to an increase in light intensity. Forest Ecology and Management, v.80, p.1-3, 1996.

DANIEL, O.; OHASHI, S.T.; SANTOS, R.A. dos. Produção de mudas de Goupia glabra (cupiúba): efeito de níveis de sombreamento e tamanho de embalagens. Revista Árvore, v.18, p.1-13, 1994.

DRIESSCHE, R. van den. Relationship between spacing in the nursery in relation to growth yield, and performance of the stock. Forest Chronicle, v.60, p.345-355, 1994.

FERREIRA, C.A.G. Aspectos de relações hídricas e de crescimento de mudas de Eucalyptus spp. produzidas em tubetes e aclimatadas. Lavras: UFLA, 1997. 64p. (Thesis - M.Sc.).

FREEZE, F. Elementary statistical methods for foresters. Washington: USDA, Forest Service, 1967. 87p. (Agriculture Handbook, 317).

GOMES, J.M.; PAIVA. H.N. Viveiros florestais (propagação sexuada). 3.ed. Viçosa: UFV, 2004. 116p.

JOHNSON, J.D.; CLINE. M.L. Seedling quality of southern pines. In: DURYEA, M.L.; DOUGHERTY, P. (Ed.). Forest regeneration manual. Dordrecht: Kluwer Academics Publishers, 1991. p.143-162.

JOSÉ, A.C. Utilização de mudas de espécies florestais produzidas em tubetes e sacos plásticos para revegetação de áreas degradadas. Lavras: UFLA, 2003. 101p. (Thesis-M.Sc.).

KIISKILA, S. The effect of seedling size on field performance. PRT's Notes from the field. Available in: http://www.prtgroup.com/ customersupport/resources/field/prtkiiskila. Accessed in: Sept. 04, 2003.

KRAMER, P.J.; ROSE JR., J.W.; Physiological characteristics of loblolly pine seedlings in relation to field performance. In: INTERNATIONAL SYMPOSIUM ON NURSERY MANAGEMENT PRACTICES FOR THE SOUTHERN PINES, Auburn, 1985. Proceedings. Auburn: Auburn University; IUFRO, 1985. p.416-440.

LELES, P.S.S. Produção de mudas de Eucalyptus camaldulensis, E. grandis e E. pellita em blocos prensados e em tubetes. Campos dos Goytacazes: Universidade Estadual do Norte Fluminense Darcy Ribeiro, 1998. 70p. (Thesis - Ph.D.).

LEOPOLD, A.C.; KRIEDEMAN, P.E.; Growth and development. New York: McGraw-Hill, 1975. 575p.

MCTAGUE, J.P.; TINUS, R.W. The Effects of seedling quality and forest site weather on field survival of Ponderosa Pine. Tree Planters' Notes. v.47, p.16-23, 1996. Available in: <www.srs.fs.fed.us/pubs/ rpc/1998-06rpc-98jun-33.pdf>. Accessed in: Sept. 10, 2001.
MEXAL, J.G.; LANDIS. T.D. Target seedling concepts: height and diameter. In: TARGET SEEDLING SYMPOSIUM MEETING OF THE WESTERN FOREST NURSERY ASSOCIATIONS, Roseburg, 1990. Proceedings. Fort Collins: USDA, 1990. p.17-37.

MOHAMED, G.H.; NOLAND, T.L.; WAGNER, R.G. Physiological perturbation in jack pine (Pinus banksiana, Lamb.) in the presence of competing herbaceous vegetation. Forest Ecology and Management, v.103, p.75-85, 1998.

MORGADO, I.F.; CARNEIRO, J.G. de A.; LELES, P.S. dos S.; BARROSO, D.G. Nova metodologia de produção de mudas de Eucalyptus grandis Hill ex Maiden, utilizando resíduos prensados como substrato. Revista Árvore, v.24, p.27-33, 2000.

NOVAES, A.B.; CARNEIRO, J.G. de A.; LELES, P.S. dos S.; BARROSO, D.G. Comportamento de mudas de Pinus taeda, L. produzidas em raiz nua e em dois tipos de recipientes, 24 meses após o plantio. Floresta, v.31, p.62-71, 2001.

NOVAES, A.B.de.; CARNEIRO, J.G. de A.; BARROSO, D.G.; LELES, P.S. dos S. Avaliação do potencial de regeneração de raízes de mudas de Pinus taeda, L. produzidas em diferentes tipos de recipientes e o seu desempenho no campo. Revista Árvore, v.26, p.675-681, 2002.

OLIVEIRA FILHO, G.H. Estudos ecológicos da vegetação, como subsídios para programas de revegetação com espécies nativas: uma proposta metodológica. Cerne, v.1, p.64-72, 1994.

PAULA, R.A. de. Metodologia para determinação de custos de qualidade, em produção de mudas de eucalipto. Campos dos Goytacazes: Universidade Estadual do Norte Fluminense Darcy Ribeiro, 1997. 97p. (Thesis - Ph.D.).

PIMENTEL-GOMES, F.; GARCIA, C.H. Estatística aplicada a experimentos agronômicos e florestais: Exposição com exemplos e orientações para uso de aplicativos. Piracicaba: FEALQ, 2002. $309 \mathrm{p}$.

REIS, G.G. dos.; REIS, M.das G.F.; RODRIGUES, F.L.; BERNARDO, A.L.; GARCIA, N.P.C. Efeito da poda de raízes de mudas de eucalipto, produzidas em tubetes sobre a arquitetura do sistema radicular e o crescimento no campo. Revista Árvore, v.20, p.137$145,1996$.

SANTOS, C.B. Efeito de modelos de tubetes e tipo de substrato na qualidade de mudas de Cryptomeria japonica (L.F.) D. Don. Santa Maria: UFSM, 1998. 65p. (Thesis - M.Sc.)

SCHMIDT-VOGT, H. Wachstum und Qualitaet von Forstpflanzen. Munique: Bayerischer Landwirtschaftverlag, 1966. 210p.

SOUTH, D.B. Planting morphologically improved pine seedlings to increase survival and growth. Forestry and Wildlife Series, v.1, p.1-14, 2000.

STEEL, R.G.D.; TORRIE. J.H. Principles and procedures of statistics - with special reference to the biological sciences. New York: McGraw-Hill, 1960. 481p.

UNDSTRÖM, E.; KEANE, M. Root architecture, early development and basal sweep in containerized and bare-rooted Douglas-fir (Pseudotsuga menziesii). Plant and Soil. v.217, p.65-78, 1999.

TINUS, R.W. Root growth potential as an indicator of drought stress history. Tree Physiology, v.16, p.795-799, 1996a.

TINUS, R.W. The value of seedling quality testing. Tree Planters' Notes, v.47, 1996b. Available in: http://www.na.fs.fed.us/spfo/rngr/tpn/ vol47-2/comments_47-.htm. Accessed in: Oct. 6, 2001.

WAKELEY, P.C. Panting the southern pines. Washington: Forest Service, USDA, 1954. 233p.

Received August 16, 2005

Accepted January 10, 2007 